\title{
Effects of Different Plant Products against Pig Mange Mites
}

\author{
E. MÄGI ${ }^{1}$, T. JÄRVIS ${ }^{1}$, I. MILLER $^{1}$ \\ ${ }^{1}$ Estonian University of Life Sciences, Institute of the Veterinary Medicine and Animal Sciences, Tartu, \\ Estonia \\ Received November 4, 2005 \\ Accepted March 16, 2006
}

\begin{abstract}
Mägi, E., T. Järvis, I. Miller: Effects of Different Plant Products against Pig Mange Mites. Acta Vet. Brno 2006, 75: 283-287.

The objective of this study was to determine the antiparasitic efficiency of herbal-based products. Four medicinal plant species extracts in $10 \%$ ethanol solutions (hogweed Heracleum sosnowskyi Manden, mugwort Artemisia vulgaris L., tansy Tanacetum vulgare L., wormwood Artemisia absinthium L.), and seven essential medicinal ethereal oils used in $1 \%$ emulsions (garlic Allium sativum L., black pepper Piper nigrum L., juniper Juniperus communis L., citronella grass Cymbopogon nardus Rendle, pennyroyal Mentha pulegium L., eucalyptus Eucalyptus globulus Labill., tea tree Melaleuca alternifolia Gheel) were tested a on pig farm in Estonia to control swine sarcoptic mange mites (Sarcoptes scabiei var. suis (L. 1758) Latreille, 1802). Trial groups (6 pigs each) were treated over the whole body twice, with one week interval in between; one group was left as untreated control. All the preparations used inhibited the development of and were more or less lethal to mange mites. Tea tree and citronella volatile oil preparations proved to be the most effective (viability of mites $<5 \%$ in 4 weeks). The most active extract of tested ethanol solutions was obtained from hogweed seeds: after two treatments of pigs, $57-93 \%$ of parasites died in $2-4$ weeks. The extracts of local plants tansy and wormwood diminished the number of mites up to $44 \%$ within the first week after treatments. The results indicate that plant extracts may be further tested in practice as alternatives to drugs of synthetic origin.
\end{abstract}

Swine sarcoptosis, farm trials, herbal preparations

Several arthropod reproductive inhibitors and repellents have been extracted from certain plants from ancient times. These extracts affect the feeding behaviour and life cycle of parasites (Tooning et al. 1988; Green et al. 1991; Wells et al. 1993; Perich et al. 1995). As pesticides of synthetic origin may have a negative impact on the environment, and pest resistance to toxic chemicals can develop after repeated applications, the use of natural products has become more popular. For example, pyrethrins are insecticides derived from the chrysanthemum plant. They are common ingredients of parasite control products and are neurotoxic at high levels ( $\mathrm{H}$ an sen et al. 1994). The most commonly used derivates of citrus fruits are D-limonene and orange essential oils. The main advantage of such products is a high margin of safety for warm-blooded organisms (Hoo ser et al. 1986). Garlic has been widely studied for its immunity boosting properties. Numerous studies indicate that the compound allicin, found in fresh garlic, has antibiotic, antiparasitic and antifungal properties (Ankri and Mirelman 1999; Rivlin 2001; Viegi et al. 2003; Anthony et al. 2005). Nowadays we know that about 2000 herbal species of the whole world might be used to control arthropod pests.

In order to work out a theoretical basis of veterinary herbal medicine in Estonia, the possibilities for the use of several plant products as natural pesticides will be investigated in local conditions. Herbal preparations were prepared in the laboratory for the purpose of using them for treating swine test groups. Databases and new technologies (Dr. Duke's Phytochemical and Ethnobotanical Databases 1992; Viegi et al. 2003) can help us, but plant efficacy must be studied with laboratory tests and on farm trials. On the basis of

Address for correspondence:

Dr. Erika Mägi

Institute of Veterinary Medicine and Animal Science

Estonian University of Life Sciences

Kreutzwaldi 62, 51014 Tartu, Estonia
Phone: 3727313225

Fax: 3727313230

E-mail: erika.magi@emu.ee

http://www.vfu.cz/acta-vet/actavet.htm 
these investigations and our previous results of in vitro tests (Mägi and Kaarma 1999; Kaarma et al. 2000), several plant extracts were selected for pig treatments. Hogweed (Heracleum sosnowskyi Manden), wormwood (Artemisia absinthum L.), mugwort (Artemisia vulgaris L.) and tansy (Tanacetum vulgare L.), have shown the highest efficacy against swine ectoparasites in our laboratory tests with local Estonian herbs. As many of the active ingredients in manufactured drugs are originally derived from plant compounds and used against diseases, several products of the Australian essential oil company New Directions Ltd. have been used comparably in our farm tests: garlic (Allium sativum L.), black pepper (Piper nigrum L.), juniper (Juniperus communis L.), citronella grass (Cymbopogon nardus Rendle), pennyroyal (Mentha pulegium L.), eucalyptus (Eucalyptus globulus Labill.) and tea tree (Melaleuca alternifolia Gheel).

Recent studies abroad as well as in our laboratory have proved that the most effective preparations compared with traditionally used antibiotics are herbal-based products produced from high quality herbs from all over the world ( Schmutter and A scher 1980; Kaarma and Mägi 1994; Smith 1995; Kaarma et al. 1999; Mägi and Kaarma 1999; Viegi et al. 2003; Walton et al. 2004; Anthony et al. 2005).

\section{Materials and Methods}

From 1999 to 2004 several farm trials with natural antiparasitic products were carried out on experimental pig unit Heko Pöld in the Tartu district, Estonia. Investigations were carried out to determine the effect of 11 plant extracts and ethereal essential oils on swine mange mites. Seventy-two sows showing clinical signs of swine sarcoptosis were used in our trials. Trial groups of 6 pigs each were treated over the whole body twice, with a week intervals, one group was allocated as untreated control. Clinical evaluations were done weekly and observations continued up to 5 weeks after treatments. Scrapings of marked $10 \mathrm{~cm}^{2}$ infested skin area from each pig were examined microscopically to determine the number of live mites. According to the results of our previous in vitro tests (Mägi and Kaarma 1999), several plant products were selected for pig treatments.

Plants used in ethanol extracts:

1. Hogweed (Heracleum sosnowskyi Manden) - contains natural insect growth regulators, which break the arthropod lifecycle and prevent larvae from maturing Lipnitskij 1996; Mägi and Kaarma 1999).

2. Mugwort (Artemisia vulgaris L.) - contains repellents and toxic alkaloids (Viegi et al. 2003).

3. Tansy (Tanacetum vulgare L.) - contains ethereal oils and toxic alkaloids (Viegi et al. 2003).

4. Wormwood (Artemisia absinthium L.) - contains repellents and ethereal oils (Viegi et al. 2003).

All local plant herbs were collected from natural growing places and dried in room temperature. Dried herbs (hogweed seeds, tansy flowers, mugwort and wormwood leaves) were infused in $70 \%$ ethanol solutions in volume relation of $1 / 4$ for 24 hours. These home-produced extracts were stored in small glass bottles at $+4{ }^{\circ} \mathrm{C}$. Before swine external treatments, $10 \%$ water solutions were made from ethanol extracts (Kaarma and Mägi 1994).

All 7 manufactured essential medicinal ethereal oils used in farm tests were $100 \%$ pure Australian products (New Directions Ltd., Australia):

1. Garlic (Allium sativum L.) - contains sulphur compounds, particularly diallyl sulphide. Garlic oils are the oldest kind of manufactured preparations and were made long before research identified the active ingredients (Ankri and Mirelman 1999; Rivlin 2001; Anthony et al. 2005).

2. Black pepper (Piper nigrum L.) - ethereal oil is produced from black pepper berries. As an antiseptic, antitoxic and antibacterial agent (Lydon and Duke 1989; Anthony et al. 2005) was used to determine its possible repellent or lethal effects on swine mange mites.

3. Juniper (Juniperus communis L.) - has been used historically to disinfect the air. Diffusing or evaporating juniper oil can also be used for the same purpose. Juniper promotes metabolism, is antiseptic, detoxifying, toning and antibacterial (Viegi et al. 2003).

4. Citronella grass (Cymbopogon nardus Rendle) - volatile oil obtained from the leaves and stems of the citronella plant contains citronellal, geraniol, camphor-like camphene, borneol and methyleugenol (Dr. Duke's Phytochemical and Ethnobotanical Databases 1992). Because of its association with insect repellent qualities, citronella is an excellent alternative to chemical methods against fleas and biting insects.

5. Pennyroyal (Mentha pulegium L.) - oil is distilled from the herb of this mint. The chief constituent (ketone pulegone) is known to be repellent to insects, especially fleas (Viegi et al. 2003).

6. Eucalyptus (Eucalyptus globulus Labill.) - oil is distilled from fresh leaves and branch tips. The primary active constituent is cineol, also known as eucalyptol (Dr. Duke's Phytochemical and Ethnobotanical Databases 1992; Bennet-Jenkins and Bryant 1996). Its camphoraceous aroma has antiseptic qualities and is known as insect repellent.

7. Tea tree (Melaleuca alternifolia Gheel) - oils act both as a bactericide/antiseptic and as an antifungal agent, 
kill certain viruses and provide a boost to the immune system (Walton et al. 2004; Anthony et al. 2005). Melaleucas grow only in the South Wales region of Australia.

To test the viability of swine mange mites, medicinal plant essential oils were used in $1 \%$ emulsions. The oneway analysis of variance (One-way Anova) was used to test the hypotheses. Comparisons of means were used to compare different groups.

\section{Results}

All the tested plant products occurred to be lethal against swine mange mites. Insect reproductive inhibitors and repellents, extracted from medicinal plants, affected the reproduction of parasites. The results of our tests are presented in Table 1. The effectiveness of 6 plant products - mugwort, wormwood, garlic, tansy, hogweed, and tea tree - is illustrated in Fig. 1. Already in the first post-treatment examination the number of mites was significantly lower in scrapings from the treated pigs, and a great improvement of pigs was noticed two weeks after the treatments.

Table 1. Pig mange mite treatment with various plant products: pair-wise comparisons of means (4 weeks after treatments)

\begin{tabular}{|c|c|c|c|c|c|c|}
\hline Variants & Parasitic stage & Number of live parasites & \multicolumn{4}{|c|}{ Homogenous groups } \\
\hline Control & Adult & 101.31 & $\mathrm{I}$ & & & \\
\hline Mugwort & $"$ & 18.22 & & I & & \\
\hline Juniper & $"$ & 14.62 & & I & & \\
\hline Black pepper & $"$ & 11.75 & & I & I & \\
\hline Wormwood & $"$ & 10.98 & & $\mathrm{I}$ & $\mathrm{I}$ & \\
\hline Eucalyptus & $"$ & 10.69 & & $\mathrm{I}$ & $\mathrm{I}$ & \\
\hline Garlic & $"$ & 10.64 & & $\mathrm{I}$ & $\mathrm{I}$ & \\
\hline Tansy & $"$ & 8.82 & & & $\mathrm{I}$ & $\mathrm{I}$ \\
\hline Pennyroyal & $"$ & 6.75 & & & $\mathrm{I}$ & $\mathrm{I}$ \\
\hline Hogweed & $"$ & 6.66 & & & $\mathrm{I}$ & $\mathrm{I}$ \\
\hline Citronella & $"$ & 4.82 & & & & $\mathrm{I}$ \\
\hline Tea tree & $"$ & 1.45 & & & & I \\
\hline
\end{tabular}

Control $=$ non-treated group

Critical t-value $=3.69$

Critical value for comparison $=9.33$

Rejection level $=0.05$

The most active extract of tested local plant extracts was obtained from hogweed. After treatments with $10 \%$ extract of hogweed seeds $57-93 \%$ of parasites died in 2 - 4 weeks. The extracts of tansy and wormwood diminished the number of parasites by up to 44-90\% in 1- 4 weeks (Fig. 1). The solutions of mugwort proved to be less effective against mites: 4 weeks after treatments the number of parasites observed in scabs appeared to be $18 \%$ of the initial level. Regardless of the final number of live mites, it may be concluded that mugwort extract solutions significantly reduced the number of mites in the first $1-2$ weeks (42-72\%).

As our previous results with imported essential ethereal oils have shown, all the tested products were proved to be effective against sarcoptic mange mites: in their $0.5-2 \%$ water emulsions the lethality in vitro was registered up to $95-100 \%$ in 24 hours (Mägi and Kaarma 1999). Thus, carrying out the farm trials, acaricidal effects of $1 \%$ ethereal emulsions in comparison with $10 \%$ local plant extract solutions were established and thoroughly studied. The most effective ethereal oil preparation against mange mites appeared to be tea tree oil - after two weeks the number of mites in scabs diminished by $85 \%$ (Fig. 1). After 4 weeks, comparisons of means were used to compare the results of different 


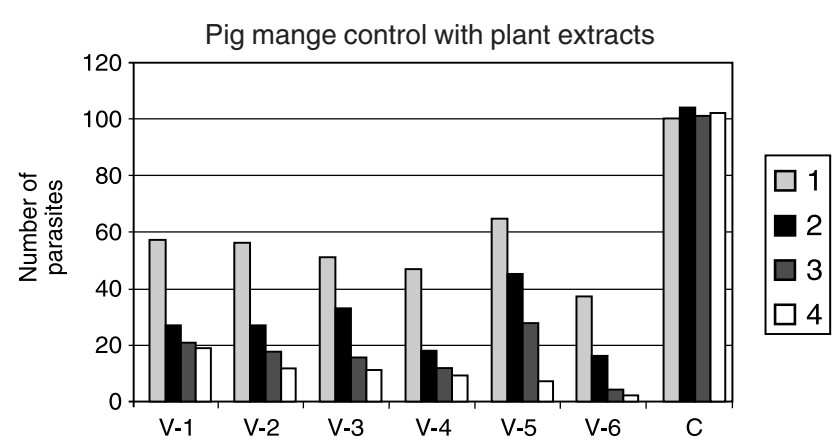

Fig. 1. Effects of different plant products on viability of swine mange mites

$1=$ one week after treatments

$2=$ two weeks after treatments

$3=$ three weeks after treatments

$4=$ four weeks after treatments

$\mathrm{V}-1=$ mugwort

$\mathrm{V}-2=$ wormwood

$$
\begin{aligned}
& \mathrm{V}-3=\text { garlic } \\
& \mathrm{V}-4=\text { tansy } \\
& \mathrm{V}-5=\text { hogweed } \\
& \mathrm{V}-6=\text { tea tree } \\
& \mathrm{C}=\text { control (non-treated group) }
\end{aligned}
$$

variants (Table 1). Our data indicate that no essential differences $(<9.33)$ exist between the variants of the same homogenous group. There are 4 columns according to our results because there are 4 groups of similar means. The first group contains the means of the control variant and it differs significantly from other groups. Tea tree, citronella, hogweed, pennyroyal and tansy which belong to the fourth group, diminished the number of parasites up to $1.45 \%-8.82 \%$ from the initial level.

\section{Conclusions}

The tested dilutions of medicinal plants proved to be effective against pig mange mites and they reduced considerably the number of sarcoptic mange mites. Tea tree and citronella volatile oil dilutions proved to be the most active preparations.

The extracts of local plants containing insect reproductive suppressors and repellents, such as hogweed, tansy and wormwood, require more attention and further investigation.

It became evident that the plant extracts may be tested further in practice as alternatives to drugs of synthetic origin.

\section{Vliv různých rostlinných produktů na zákožku svrabovou u prasat}

Cílem studie bylo ověřit antiparazitární účinnost rostlinných produktů na zákožku svrabovou. Extrakt čtyř léčivých rostlin v 10\% ethanolu (bolševník velký Heracleum sosnowskyi Manden, starček Artemisia vulgaris L., vratič obecný Tanacetum vulgare L., pelyněk Artemisia absinthium L.), a 7 léčivých éterických olejů použitých v $1 \%$ emulzích (česnek Allium sativum L., pepř černý Piper nigrum L., jalovec obecný Juniperus communis L., citronella Cymbopogon nardus Rendle, máta obecná Mentha pulegium L., eukalyptus Eucalyptus globulus Labill., čajovník australský Melaleuca alternifolia Gheel) bylo testováno v chovu prasat v Estonsku s cílem omezit výskyt svrabu (Sarcoptes scabiei var. suis (L. 1758) Latreille, 1802). Pokusné skupiny (každá o 6 prasatech) byly ošetřeny po celém povrchu těla dvakrát týdně; kontrolní skupina byla ponechána bez ošetření. Všechny preparáty inhibovaly vývoj zákožek a byly pro ně více nebo méně letální. Éterické oleje čajovníku australského Melaleuca alternifolia Gheel a citronelly byly nejúčinnější (životnost zákožek byla $<5 \%$ v průběhu 4 týdnů). Nejaktivnější extrakt testovaných roztoků 
v etanolu byl získán ze semen bolševníku velkého: po dvou ošetřeních prasat uhynulo na nich 57 - 93\% parazitů během 2 - 4 týdnů. Extrakty lokálních rostlin - vratiče obecného a pelyňku snížily počet zákožek o 44 \% během prvního týdne po ošetření. Tyto výsledky naznačují, že testování a poté využívání rostlinných extraktů se jeví jako nadějná alternativa $\mathrm{k}$ látkám syntentického původu.

\section{Acknowledgements}

The study was supported by the project B2099LANH02.

\section{References}

ANKRI S, MIRELMAN D 1999: Antimicrobial properties of allicin from garlic. Microbes Infect 2: 125-129

ANTHONY JP, FYLE L, SMITH H 2005: Plant active components - a resource for antiparasitic agents? Trends in Parasitol 21, 10: 462-468

BENNET-JENKINS E, BRYANT C 1996: Novel anthelmintics. Int J Parasitol 26: 937947

DUKE'S Phytochemical and Ethnobotanical Databases 1992: http://www.ars-grin.gov/duke/

GREEN MM, SINGER JM, SUTHERLAND DJ, HIBBEN CR 1991: Larvicidal activity of Tagetes minuta (marigold) toward Aedes aegypti. J Amer Mosq Control Ass 7: 282-286

HANSEN SR, STEMME KA, VILLAR D 1994: Pyrethrins and pyrethroids in dogs and cats. Comp Cont Ed Pract Vet 16: 707-712

HOOSER SB, BEASLEY VR, EVERITT JI 1986: Effects of an insecticidal dip containing d-limonene in the cat. J Am Vet Med Assoc 189: 905-908

KAARMA A, MÄGI E 1994: Effects of different local plant preparations on sarcoptic mange in swine. Vet Med '94: 156-161

KAARMA A, MÄGI E. LAANEOJA L 1999: Biological control principles of animal ectoparasites. Bull Scand Soc Parasitol 9, 1: 38-39

KAARMA A, MÄGI E, SAHK M 2000: The use of natural plant extracts against animal ectoparasites. Journal of Agricultural Science: Transactions of the Estonian Academic Agricultural Society 12: 19-22

LIPNITSKIJ SS 1996: Safety and antiparasitic efficacy of a formulation of Heracleum sosnowskyi. Vestsi Akademii Agrarnyh Nauk Belarusi 3, 74: 77

LYDON J, DUKE S 1989: The potential of pesticides from plants, pp. 1-41 in Craker, L. \& Simon, J., eds, Herbs, Spices \& Medicinal Plants: Recent Advances in Botany, Horticulture, \& Pharmacology, v. 4, Oryx Press, Phoenix, 267 p.

MÄGI E, KAARMA A 1999: Plant extracts as antiparasitic natural products. pp. 34-41. In: Tiirats T (Ed.). Vet Med '99. OÜ Farmax, Tartu

PERICH MJ, WELLS C, BERTSCH W, TREDWAY KE 1995: Isolation of the insecticidal components of Tagetes minuta ( Compositae) against mosquito larvae and adults. J Am Mosq Control Ass 11: 307-310

RIVLIN RS 2001: Historical perspective on the use of garlic. J. Nutrition 131: 951-954

SCHMUTTER H, ASCHER KRS 1980: Natural pesticides from the neem tree (Azadirachta indica A. Juss). Proc. First Intern. Neem Conf., Rottach, Fed. Rep. of Germany, June 16 - 18, 297 p.

SMITH CA 1995: Searching for safe methods of flea control. J Am Vet Med Assoc 206: 1137-1143

TOONING YC, SCHOOLEY DA, BAKERT FC 1988: Isolation of insect juvenile hormone III from a plant. Nature 333 (6169): 170-171

VIEGI L, PIERONI A, GUARRERA PM, VANGELISTI R 2003: A review of plants used in folk veterinary medicine in Italy as basis for a databank. J Ethnopharmacol 89: 221- 244

WALTON SF, MCKINNON M, PIZZUTTO S, DOUGALL A, WILLIAMS E, CURRIE BJ 2004: Acaricidal activity of Melaleuca alternifolia (Tea Tree) oil. Arch Dermatol 140: 563-566

WELLS C, BERTSCH W, PERICH M 1993: Insecticidal volatiles from the marigold plant (Genus Tagetes). Effect of species and sample manipulation. Chromatographia 35: 209-215 